\title{
Urban Environmental Aesthetic and Identity: The Case of Masouleh, Iran
}

\author{
Kentsel Çevresel Estetik ve Kimlik: Masouleh Örneği, İran
}

\section{Azadeh Rezafar}

\begin{abstract}
Urban environmental aesthetics and place identity have begun to take their place on the design and planning agenda, especially in recent years. Urbanization resulting from competition between cities has caused the loss of identity and aesthetics in cities all over the world. The decreasing use of traditional building methods and planning, without consideration of the local context, by developers, authorities, and even administrators of cities has led cities to resemble each other. In light of these developments, the shape, form, texture, and especially identity and aesthetics of settlements become important in planning and urban design. While the concepts of aesthetics and urban identity are difficult to define, there are some parameters to evaluate them.

This paper has two main objectives. The first is to determine parameters to evaluate aesthetics and urban identity. The second is to check these parameters over historical and touristic settlements. For this purpose, the concepts of aesthetics and spatial identity will be explained within the scope of the literature. The city of Masouleh in Iran has been chosen as an example of a historical and touristic settlement. The systematic development of the historical settlement, as well as the landscape, identity, and aesthetics of the environment's harmony and texture, were evaluated with a descriptive-analytical approach methodology based on the parameters revealed in the scope of the research. The findings aim to reveal the aesthetics and identity of historical residential areas. Including this information in scientific studies will lead to the design of more aesthetic settlements in the future.
\end{abstract}

\section{Keywords}

Aesthetics, Identity, Historical Settlements, Masouleh, Iran

\section{Öz}

Kent, çevre estetiği ve mekân kimliği, özellikle son yıllarda tasarım ve planlama gündemindedir. Rekabete dayalı kentleşme, tüm dünyada kimlik ve estetik kaybına sebep olmaktadır. Geleneksel yapı yöntemlerinin kullanımının azalması ve geliştiriciler, yetkililer ve hatta kent yöneticileri tarafından yerel bağlam dikkate alınmadan yapılan planlar tüm kentlerin birbirine benzemesine yol açmaktadır. Kentlerin gitgide birbirine benzemeye başlamasıyla, şekli, formu, dokusu ve özellikle kimlik ve estetiği, günümüzde önem kazanmıştır. Estetik ve kentsel kimlik kavramlarının tanımlanması zor olmasına rağmen, onları değerlendirmek için bazı parametreler bulunmaktadır.

Bu araştırmanın iki temel amacı bulunmaktadır. Birincisi, estetik ve kentsel kimliği değerlendirmek için parametrelerin belirlenmesidir. İkincisi ise, bu parametreleri, tarihî ve turistik yerleşim üzerinden denetlemektir. Bu amaçla estetik ve

* Correspondence to: Azadeh Rezafar (Asst. Prof.), Istanbul Arel University, Faculty of Engineering and Architecture, Department of Architecture, Istanbul, Turkey. E-mail: azadehrezafar@arel.edu.tr ORCID: 0000-0002-0266-4826

To cite this article: Rezafar, Azadeh. "Urban Environmental Aesthetic and Identity: The Case of Masouleh, Iran." Art-Sanat, 17(2022): 397-418. https://doi.org/10.26650/artsanat.2022.17.842486 
mekân kimliği kavramları, literatür araştırması kapsamında ele alınmıştır. Çalışmada İran'ın Masouleh kenti, tarihî ve turistik yerleşime örnek olarak seçilmiştir. Tarihî yerleşimin sistematik gelişimi ile peyzaj, çevresel uyum ve dokusundaki kimlik ve estetik, araştırma kapsamında ortaya koyulan parametreler üzerinden betimsel-analitik yaklaşım metodolojisi ile değerlendirilmiştir. Bu araştırma bulguları, tarihî yerleşim alanlarının estetiği ve kimliğini ortaya koymaya yönelik bilgilerdir. Bu bilgilerin bilimsel çalışmalara dâhil edilmesinin gelecekte daha estetik yerleşimlerin tasarlanmasına yardımcı olabileceği düşünülmektedir.

\section{Anahtar Kelimeler}

Estetik, Kimlik, Tarihi Yerleşimler, Masouleh, İran

\section{Genisletilmis Özet}

Kentler çok boyutlu sosyal, kültürel, doğal, tarihî, mimari ve yapay öğeleri içinde barındıran karmaşık ve dinamik sistemlerdir. Endüstrileşme ile başlayan ve günümüzde hız kazanan kentleşme ve göç süreciyle birlikte, tasarımcılar, yetkililer ve hatta yöneticiler tarafından yerel bağlam, tarih, kültür, estetik, geleneksel yapı yöntemleri ve planlama, dikkate alınmadan kentsel yerleşim alanları gelişmektedir. Buna ek olarak kentler arası rekabete dayalı planlı veya plansız kentleşme, tüm dünya kentlerinde kimlik ve estetik kaybına neden olmaktadır. Gitgide yeşil alanların azalması ve birbiriyle uyumsuz yüksek yapıların artması, kentsel estetiği ve kimliği olumsuz etkilemektedir. Böylece kentleşme sürecinde, tarihî, kentsel, estetik değerlerin yitirilmiş olması, özellikle son yıllarda kentsel estetik ve mekânsal kimlik kavramlarının kentsel tasarım ve planlama gündeminde yer almasına yol açmıştır. Herhangi bir yerleşimin kırdan kente geçişi, literatürde kentleşme olarak ifade edilmektedir. Yerel bağlam ve mimari estetikten yoksun olarak hızlıca gelişen yerleşim alanları, tüm kentlerin birbirine benzemesine sebep olmaktadır. Kendi özgün kültür ve kimliğinin kaybolduğu birbirine benzeyen kentler, aynı zamanda görsel kirliliğe de yol açmaktadır. Bu durumun artması ile birlikte, yerleşim yerlerinin şekli, formu, dokusu ve özellikle kimlik ve estetiği günümüz planlama ve kentsel tasarım gündeminde önem kazanmıştır. Estetik, kentlerin birbirinden ayırt edilmesini sağlayan bir değerdir. Kimlik ise, bir yeri diğerlerinden farklı kılan sürekli benzerlikler ve birlikteliklerdir. Estetik duyarlılık ile tasarlanmış çevre, fiziksel, sosyal ve ruhsal sağlığın yanı sıra, yaşam kalitesini yükseltip kentin algılanmasını kolaylaştırıp gayrımenkul değer artışını sağlamaktadır.

Doğada ve sanatta güzeli konu edinmek, onu aramak ve algılamak olarak tanımlanan estetik, tarih boyunca, 'güzel' kavramı ile ilişkilendirilmiştir. Bu tanım, kendine özgülük ve özgünlük kavramıyla beraber, kimliği ifade etmektedir. İnsanlar için estetik kabul edilen güzel bir kent imgesi aynı zamanda insanca yaşamın gerekliliğini sağlamaktadır. Diğer taraftan kentsel kimlik doğal, yapılaşmış ve sosyal çevreden oluşmaktadır. Bu çevrelerde oluşan farklılıklar, insanların kendisine göre oluşturdukları estetik değer ve kimliktir.

Estetik kalite, fiziksel çevrenin başarılı biçimde inşa edilmesi anlamına gelse de kavramsal açıdan görecelidir. Yani estetik kavramı kişiden kişiye farklılık göster- 
mektedir. İnsan tarafindan oluşan yapılar ile doğal çevre arasında uyumun sağlanması, bu yapıların insanın sanatsal ve duygusal yönünü açığa çıkartması gereklidir. Yapılar arasındaki uyum, doğa ve yeşil alanlar, tarihi eserler, kültürel değerler, sosyal tesisler ve tüm kentsel öğelerin arasında uyumun sağlanması kentsel estetik ve kalite için gerekli parametrelerdir. Aynı zamanda yapay ve doğal elemanlar, bitki örtüsü, iklim koşulları, mimari, coğrafya, uygarlıklar ve yerel gelenekler, yaşam biçimleri, ekonomik ve politik yapı kentsel kimliğin bileşenleridir. Dolayısıyla kamusal, ortak ve kentsel omurga alanlarının estetiğini sağlamak, sosyal, kültürel ve tarihî değerleri dikkate almak, kentsel estetik ve kimliğe ulaşmak ve bütünlüğü sağlamak açısından önemlidir. Bu durum günümüz kentlerinde birtakım biçimsel müdahaleler, görsel güzellik ve süslemelerden öteye gidememektedir.

Son zamanlarda, kentsel estetik ve kimlik, mimari, kentsel planlama, tasarım ve bilimsel çalışmalara konu olmuştur. Estetik ve kentsel kimlik kavramlarının değerlendirilmesi için, literatürde bazı parametreler bulunmaktadır. Bu parametreler genel olarak kentsel tasarım çalışmalarında yer almaktadır. Kenti oluşturan biçimsel, formal ve fiziksel değerler ile imgesel veya sembolik değerler kentsel estetiği oluşturmaktadır. Şekil, oran, düzen, hiyerarşi ve mekânlar arası etkileşim gibi değerler biçimsel/ formal estetik bileşeni oluşturmaktadır. İmgesel estetik ise, yapılara insanların kültürel değer yargılarına, tecrübelerine ve bakış açılarına veya algı-anlam ilişkisine dayanarak verdikleri anlamlardır. Bunun yanı sıra ritim, harmoni, denge ve birlik ilkeleri tasarımda geçerli olan, göze hoş gelen bileşenler veya estetik parametreler olarak kabul edilmektedir. Bu parametreler aynı zamanda mimarinin dişsal estetik özelliklerini değerlendirmek için kullanılmaktadır. Dolayısıyla estetik, biçim ve anlam ile ilgili bir değerdir. Bu parametrelerin yanı sıra; estetik değerlendirme farklı toplumlar, kültürler ve kişiler arasında farklılık gösterebilmektedir. Bu kapsamda, tarihî ve turistik yerleşim alanları, yöresel kimlik ve estetik değerlerin sürekliliğinin sağlanması açısından önem arz etmektedir. Geleneksel mimari ve mekânsal çözümler ve yerel kültürel değerler bu yerleşim alanlarınının estetik özelliğini taşımaktadır. Zira, geleneksel mimari üretiminde, mimar veya herhangi bir uzmana gereksinim duyulmadan toplumum ihtiyaçlarını göz önünde bulundurarak kültürel değerler doğrultusunda mekânsal organizasyonlar yapılmaktadır. Yerel halkın sanat alışkanlıkları, gelenek ve görenekleri ve yaşam biçimleri yapı kültürüne yansıtılmaktadır.

$\mathrm{Bu}$ araştırmanın amacı, kentsel estetik ve kimlik kavramlarını turistik ve tarihî bir yerleşim alanı üzerinden değerlendirmektir. Bu amaç için Iran’ın Masouleh kenti seçilmştir. Masouleh, Zengin İran kültürü ve konut mimarisiyle literatüre sıkça konu olmuştur. Masouleh, mekân organizasyonu, konut, malzeme tipolojisi ve kentsel formu ile kendine özgü merdiven kavramıyla gelişen ve bu özelliğini koruyan bir yerleşim alanıdır. Burada mekânsal gereksinimler, yerleşimin gelenek, görenek, kültür ve yaşam biçimini en iyi şekilde karşılamaktadır. Kent, Çevre ve insana saygıllı, 
ekolojik dengeye duyarlı, bölgenin iklim verilerini dikkate alan, yerel malzemelerin kullanımına öncelik veren özgün mimari çözümleri ve detayları ile zamana ve çevreye uyumlu estetik değerler içermektedir. Kısacası, Masouleh yerleşimin ruhu (genius loci) kavramının izini karakteristik mekânsal özelliklerinde doğal ve yapılı çevresiyle sürdürmektedir.

Ne yazık ki, günümüzde kentsel estetik bilimsel şekilde ele alınmayıp kişisel ve sübjektif yorumlarla değerlendirilmektedir. Bu araştırmada betimsel-analitik yaklaşım metodolojisi kullanılmıştır. Kentsel estetik ve kimlik parametrelerini ortaya çıarmak için literatür çalışması yapılmıştır. Seçilen örnek yerleşim alanı olan Masouleh, çağdaş yerleşim tasarımında teraslı ev karakteristliğine sahiptir ve gelecekte aynı dinamiğe sahip olan yerleşimlerin estetik olarak tasarlanması için iyi bir örnek olacaktır. Aynı zamanda, geleneksel mimari parametreleri kullanmak günümüz sürdürülebilir mimari tasarımlar yaratmayı mümkün kılmaktadır. Bu çalışma ile tarihî estetik ve kimlik parametreleri yeni yerleşim alanları içinde korunup sürdürülebilir kent estetiğinin gelişmesinin sağlanabileceği düşünülmektedir. 


\section{Introduction}

Cities and regions face major challenges posed by rapid urbanization, which refers to a general increase and explosion in population and the amount of industrialization of a settlement ${ }^{1}$. The effects of rapid urbanization are urban explosion, environmental disruption, disappearing identity, deformation of the city, and city pattern transformation. Thus, with rising populations and urbanization, patterns of land use and landscape have been altered ${ }^{2}$. Indeed, the loss of place-based identity and aesthetics has occurred in tandem with the phenomenon of rapid urbanization. Cities' excessive growth, the effect of competitiveness and urbanization, has caused the loss of basic or acquired aesthetic values. Rapid and unplanned urbanization and growth has meant that cities all over the world increasingly resemble each other. After the 1980s, shape, form, texture, and especially identity and aesthetics began to gain importance, and aesthetic issues began to enter into the design and planning agenda. At the same time, the most important effect in the spatial aspects of cities and regions has been the loss of historical aesthetic parameters and the lack of consideration for vernacular and local textures in urban design and architecture. According to the literature, vernacular architecture is derived from the Latin word "vernaculus," which means native. It can also be called "the architecture of the people". ${ }^{3}$ It is a kind of building done by local people using traditional technologies. Locally available materials are used in these settlements in order to match environmental contexts and to accommodate their lives ${ }^{4}$. A process of vernacular design is based on models that attend to different necessities, for example, the climate and generating different solutions for a single problem ${ }^{5}$. In other words, the identity, intention, purpose and anonymity of the designers, the nature of the relationship to landscape and site, and the effectiveness of the response to climate are among the parameters that Rapoport defined for vernacular design ${ }^{6}$. Since historical and vernacular settlements protect their identity and continue to use local textures and aesthetic parameters, they could be an appropriate answer for today's rapid and unplanned urbanized settlements. Logical solutions for human comfort are

1 S. Uttara, Nishi Bhuvandas and Vanita Aggarwal, "Impacts of Urbanization on Environment," International Journal of Research in Engineering \& Applied Sciences (IJREAS) 2/2 (2012), 1637-1645.

2 Sivan Hisham Al Jarah, Bo Zhou, Rebaz Jalil Abdullah, Yawen Lu and Wenting Yu, "Urbanization and Urban Sprawel Issues in City Structure, A Case of the Sulaymanieh Iraqi Kurdistan Region," Sustainability 11/2 (2019), 1-21.

3 Elaheh Amini, "A Comparison Study of Vernacular Settlemnets in Iran; Case of Masouleh and Abyaneh Villages," (MSc. Thesis, Istanbul Technical University, 2019), 40-50.

4 Sadra Sahebzadeh, Abolfazl Heidari, Hamed Kamelnia, Abolfazl Baghbani, "Sustainable Features of Iran's Vernacular Architecture: A Comparative Study Between the Architecture of Hot-arid and Hot-arid-windy Regions," Sustainability 9/5 (2017), 1-28.

5 Ruben Alcolea, Aitor Acilu, "From Sea to Stone Cradle of Avant-Garde" Surveys on Vernacular Architecture, Their Significance in the 20th Century Architectural Culture Conference Proceedings (Porto: Escola Superior Artística do Porto, 2012), 83-97.

6 Maria de Betani Cavalcanti, Aesthetics and the Use of Local Resurces: the Folk Built Environment of Inland Pernambuco, IAPS 14 Book of Proceedings (Stockholm, Sweden: Royal Institute of Technology, 1996), 235-242. 
recommended by vernacular architects, as they tend to match architectural space with the conditions of their surrounding environment ${ }^{7}$. In addition to reflecting the environmental and cultural contexts in their logical solutions ${ }^{8}$, vernacular architecture protects the aesthetic values of the settlement and thus raises the quality of life.

Iran has many forms of vernacular and historical settlements. These settlements constitute the greater part of Iran's traditional architecture, which dates back almost 8000 years $^{9}$. Different climatic regions as well as diverse cultural backgrounds and ethnic groups ${ }^{10}$ created different historical settlements across the country. Local groups developed and connected their social, cultural, ritual, and symbolic values, as well as practical functions, through the art of adaption to context, which reflects the meaning of place identity. The aim of this research is to identify the identity and aesthetic features of vernacular settlements by selecting Masouleh as a case study. By revealing the aesthetic and identity features of this settlement, which responded to the city's topographical situation, and incorporating them into solutions for modern settlements, the research will show the ease with which more aesthetic settlements can be designed.

First the article will outline the research process and then provide a literature review. The concepts of aesthetic value and place identity will be discussed in this section, in order to reveal the accepted parameters in these two areas of the literature. The third section will provide an analysis of the selected case study. The architectural, geographical, landscape, and socio-cultural features of the settlement are discussed in this section. The next section evaluates the aesthetic parameters derived from the research on Masouleh, while the final section offers conclusions.

\section{Research Process}

The research process is shown in figure 1. In this research, a descriptive-analytical approach was used for the methodology. This method was used in order to reveal the theoretical investigation which was collected from research articles and studies as well as books and related scientific websites.

7 Hamidreza Shoaie, Farah Habib, "Iranian Sustainable Vernacular Architecture," Advance in Environmental Biology 7/13 (2013), 4451-4459.

8 Sahebzadeh, Heidari, Kamelnia and Baghbani, "Sustainable Features of Iran's Vernacular Architecture: A Comparative Study Between the Architecture of Hot-Arid and Hot-Arid-Windy Regions," 1-28.

9 Sahebzadeh, Heidari, Kamelnia and Baghbani, "Sustainable Features of Iran's Vernacular Architecture: A Comparative Study Between the Architecture of Hot-Arid and Hot-Arid-Windy Regions," 1-28.

10 Ehsan Reza, "Identification of Staircase House Type in Rural Architecture of Iran: Masouleh and Abyaneh Settlements," (MSc. Thesis, Eastern Mediterranean University, 2011). 


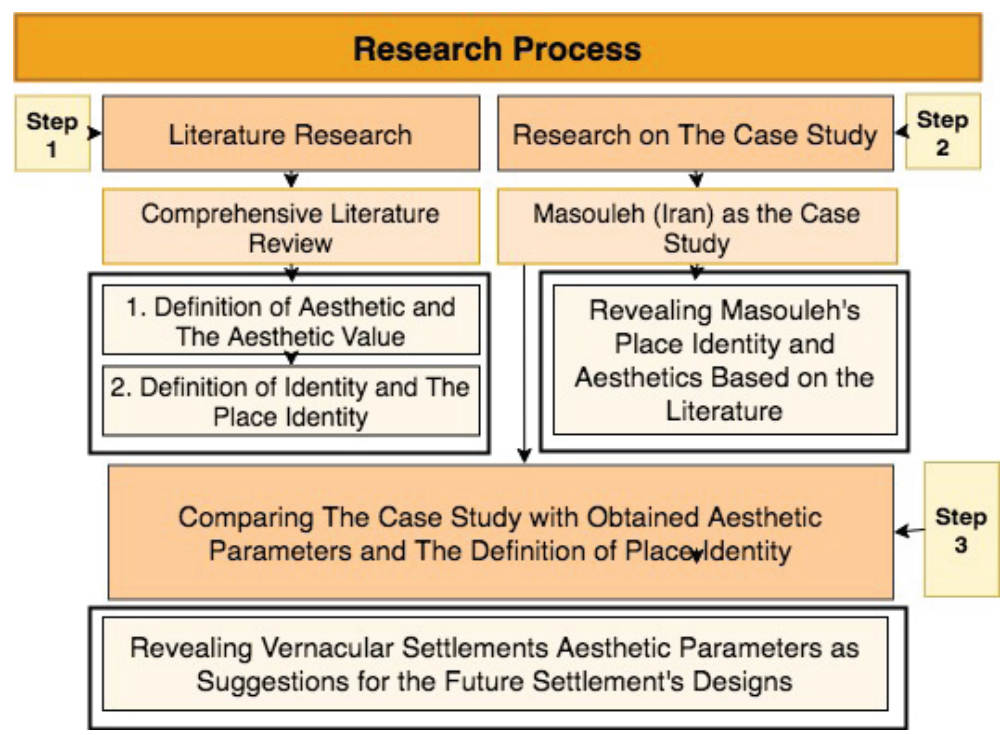

F. 1: Process of the Research (Azadeh Rezafar, 2021).

The method compares theoretical concepts within the research area. As shown in figure 1, the research is based on three steps. The first step is a literature review, which consists of two stages: 1. Definition of aesthetics and aesthetic value; 2 . Definition of identity and place identity. The second step is research on the case study in order to reveal the case study's aesthetic and identity features. The final step compares the case study with the obtained aesthetic and identity parameters, as well as an evaluation and conclusion.

\section{Literature Review}

\subsection{Aesthetic Value}

Beauty should not be neglected in discussion of aesthetic issues. The term aesthetic comes from the Greek and originally means perception ${ }^{11}$. Discussions of the term beauty date back to the beginning of the history of philosophy. One prominent definition saw beauty as the presence of order and harmony, which creates joy, pleasure, imagination, and excellent human tendencies ${ }^{12}$. The aesthetic concept of beauty also has its roots in ancient Greece, in which balance, harmony, and proportion were accepted as the basis for beauty at the time ${ }^{13}$.

11 Jörg Kurt Greuther, Aesthetics in Architecture, Translated by J. Pakzad and A. R. Homayon (Tehran: Publication Beheshti University, 2004), 20-50.

12 Mana Pirhadi, Maryam Pirhadi and Fatemeh Tavakoli, "The Study of the Concept of Aesthetics in Architecture Derived from the Ideas of Jörg Kurt Greuther," World Academy of Science, Engineering and Technology, International Journal of Urban and Civil Engineering, 4/5 (2017), 1-7.

13 Pirhadi, Pirhadi and Tavakoli, "The Study of the Concept of Aesthetics in Architecture Derived from the Ideas of Jörg Kurt Greuther,” 1-7. 
The evaluation of aesthetics is difficult and differs according to the researcher. Islamic civilization and philosophy have sought beauty as an ontological aspect in positions and meanings. In Plato's theory, aesthetics is called geometrical beauty ${ }^{14}$. At the same time, Greuther ${ }^{15}$ investigated the sense of beauty according to the three aesthetic systems classified by Peter Smith. The first system is based on order, balance and harmony. These parameters are perceived and considered as beautiful by the viewer. In the second system, because the complex messages cannot be understood all at once, the amount of information must be reduced. And in the third system, the chaotic complexity of several details must be seen together to sense the beauty, because some parts of the brain react to external stimulations without any appeal to the understanding. According to Greuther's experience, knowledge and psychosocial factors are influential in aesthetic evaluation.

Nasar classified aesthetics in formal and symbolic terms. In his analysis, shapes, proportions, rhythms, scale, degree of complexity, color, illumination and shadows, composition and the system of spatial relations, incongruity, ambiguity, surprise, novelty and order represent the formal aesthetics of a work. Since contemporary beauty is based on the aspects of appearance, it can be argued that formal aesthetic parameters represent beauty aspects more. While the symbolic aesthetic is related to experience building through content variables, these variables are not defined solely by the physical characteristics of buildings. The meaning of the structure provides a sense of belonging to a place, which reflects the individual's internal representations of the building and the meanings associated with it, which in turn reflect symbolic aesthetic parameters ${ }^{16}$. Lang described the nature of the aesthetic experience in his article as the sensory, formal and symbolic interaction between people and their built environments. While symbolic and formal aesthetic parameters are defined much as they are in Nasar, sensory aesthetics are defined as relating to the satisfaction of sensations from the environment, which are multidimensional and result from the colors, odors, sounds and textures of the environment ${ }^{17}$.

In this sense, Rezafar and Turk have evaluated formal urban aesthetic parameters in architecture, urban design and planning, and have identified the eight factors that are most influential in urban aesthetics: character and identity; green design; compatibility between identity and design; protection for continuity and the natural environment; tall buildings; plan-based versus project-based development; harmony

14 Pirhadi, Pirhadi and Tavakoli, "The Study of the Concept of Aesthetics in Architecture Derived from the Ideas of Jörg Kurt Greuther," 1-7.

15 Greuther, Aesthetics in Architecture, 30.

16 Jack Nasar, "Urban Design Aesthetics the Evaluative Qualities of Building Exteriors," Environment and Behavior 26/3 (1994), 377-401.

17 Jon Lang, Symbolic Aesthetics in Architecture: Toward a Research Agenda, (New York: Cambridge University Press, 2013), 11. 
between groups of buildings; and interior design. Pirnia has suggested that Iranian art and architecture possess distinct features and identity from history. These features are: being humanistic and proportional, abstinence from inanity, having the structure as an aesthetic element, self-sufficiency and introversion ${ }^{18}$. Hosseini and Zand Karimi ${ }^{19}$ have added purity in shape and volume, symmetry, and colorfulness to Pirnia's parameters, which can be found in most buildings using Iranian Islamic architecture. Nelson Goodman believes in the effects of density and repleteness in aesthetics. Norberg-Schulz described the meaningful system of architecture with all the elements, structure and relations ${ }^{20}$. All these parameters are summarized in Table 1.

Table 1: Aesthetic Features in Architecture and Urban Design Area Defined by Different Authors (Azadeh Rezafar, 2021)

\begin{tabular}{|c|c|}
\hline $\begin{array}{c}\text { Authors, Who Revealed Aesthetic/Beauty } \\
\text { Parameters }\end{array}$ & Revealed Aesthetic/Beauty Parameters \\
\hline $\begin{array}{l}\text { According to Greuther, based on Peter Smith's } \\
\text { Description }\end{array}$ & $\begin{array}{l}\text { 1. Order, balance and harmony } \\
\text { 2. Reducing of information } \\
\text { 3. Chaotic complexity of several details }\end{array}$ \\
\hline According to Nasar (1994) & $\begin{array}{l}\text { 1. Formal (shapes, proportions, rhythms, } \\
\text { scale...) } \\
\text { 2. Symbolic (experience building by way } \\
\text { of content variables, the meaning of the } \\
\text { structure, a sense of belonging to a place...) }\end{array}$ \\
\hline According to Lang (2013) & $\begin{array}{l}\text { 1. Formal (shapes, proportions, rhythms, } \\
\text { scale...) } \\
\text { 2. Symbolic (experience building by way } \\
\text { of content variables, the meaning of the } \\
\text { structure, a sense of belonging to a place...) } \\
\text { 3. Sensory (results from the colors, odors, } \\
\text { sounds, and textures of the environment...) }\end{array}$ \\
\hline According to Nelson Goodman (1976) & 1. Density and repleteness \\
\hline According to Hendrix (2012) & $\begin{array}{l}\text { 1. The meaning of architecture (intellectual, } \\
\text { formal, expressionistic ideas and spiritual) }\end{array}$ \\
\hline According to Norberg-Schulz (1965) & $\begin{array}{l}\text { 1. Meaningful system of architecture with all } \\
\text { the elements, structure and relations }\end{array}$ \\
\hline
\end{tabular}

18 Mohammad Karim Pirnia, Stylistics of Iranian Architecture (Iran, Tahran, Pazhuhande Publishing, 2003), 26-36.

19 Bahareh Hosseini and Atefeh Zand Karimi, "A Brief Survey on the Principles of Iranian Islamic Architecture," Archi-Cultural Translations through the Silk Road 2nd International Conference, Mukogawa Women's University (Nishinomiya, Japan, 2012), 318-323.

20 Saleem Dahabreh, " The Aesthetics Symptoms of Architectural Form: The Case of Barcelona Museum of Contemporary Art by Richard Meier," International Journal of Engineering Research and Technology 13/ 6 (2020), 1409-1419. 


\begin{tabular}{|c|c|}
\hline According to Rezafar and Turk (2018) & $\begin{array}{l}\text { 1. Character and identity } \\
\text { 2. Green design } \\
\text { 3. Compatibility between identity and design } \\
\text { 4. Protection for continuity and the natural } \\
\text { environment } \\
\text { 5. Tall buildings } \\
\text { 6. Plan-based versus project-based development } \\
\text { 7. Harmony between groups of building } \\
\text { 8. Interior design }\end{array}$ \\
\hline $\begin{array}{l}\text { According to Pirnia (2003) about Iranian } \\
\text { Architecture }\end{array}$ & $\begin{array}{l}\text { 1. Being humanistic and proportionality } \\
\text { 2. Abstinence from inanity } \\
\text { 3. Having structure as aesthetic elements } \\
\text { 4. Self-sufficiency } \\
\text { 5. Introversion }\end{array}$ \\
\hline $\begin{array}{l}\text { According to Hosseini and Zand Karimi (2012) } \\
\text { about Iranian Architecture }\end{array}$ & $\begin{array}{l}\text { 1. Being humanistic and proportionality } \\
\text { 2. Abstinence from inanity } \\
\text { 3. Having structure as aesthetic elements } \\
\text { 4. Self-sufficiency } \\
\text { 5. Introversion } \\
\text { 6. Purity in shapes and volumes } \\
\text { 7. Having symmetry } \\
\text { 8. Being colorful }\end{array}$ \\
\hline
\end{tabular}

\subsection{Place Identity}

An object is described as having an identity when it is distinctive, separable and without equivalence to other objects, individuals and unique entities ${ }^{21}$. Place identity can be described in these same terms. Monotony in urban environments can be prevented by placing the character of the environment under the concept of identity. Spaces and areas are generally defined in relation to the activities and life with identity. The distinguishing elements of a property do not change in different situations under the concept of identity and logical connection of the individual with the environment. Identity is a dynamic phenomenon and is never stable ${ }^{22}$. Different dimensions such as physical size, tangible versus symbolic, and experienced versus unknown or unexperienced can be communicated through the term place identity ${ }^{23}$. Different parts of a place in urban areas, such as buildings, public spaces, squares and streets, are what create urban identity. Hence, place has been defined as a space with its own

21 Şebnem Arbak, An Analysis on the Transformation of Urban Identity, the Case of Bodrum (MSc. Thesis, Middle East Technical University, 2005), 12; Azadeh Rezafar, Aesthetic Control Management, The Case of Istanbul (Ph.D. Thesis, Istanbul Technical University, 2019), 8-10.

22 Rogayeh Mansouri Parsa and Zohre Torabi, "Explaining the Concept of Identity and Sense of Place in Residential Environment and Lifestyle," Kuwait Chapter of Arabian Journal of Business and Management Review 4/5 (2015), 27-43.

23 Ibrahim Mostafa Eldemery, "Globalization Challenges in Architecture," Journal of Architecture and Planning Research 26/4 (2009), 334-354. 
material substance, color, texture and form, which gives it a distinctive character ${ }^{24}$. In other words, according to Norberg-Schulz, places have their own soul (Genius Loci). A common identity comes a group of people in a single body in a specific place, thus providing the foundations for relationships, friendships and society. It is not only physical parameters that define place identity, but also meaning and the association developed between people and places ${ }^{25}$. In this sense, Relph, Montgomery and Punter advance similar definitions in their comprehensive research into place identity. According to Relph, the components of place identity are appearance and physical features, activities, and symbols and meaning. Punter suggested that a sense of place is connected to activity, physical settings and meaning, while Montgomery placed his emphasis on activities, forms and images (F. 2). In these definitions, physical features include state-built form, landscapes, townscapes, streets, intensities, landmarks, public realms, and even mountains and lakes. In other words, natural geographical features as well as manmade environments contribute to place identity. Activities indicate behavior patterns, land uses, diversity, vitality, street life, people, events and situations such as café culture. Meanings denote attractions, qualitative assessments, experiences, receptivity and even interactions with users ${ }^{26}$.

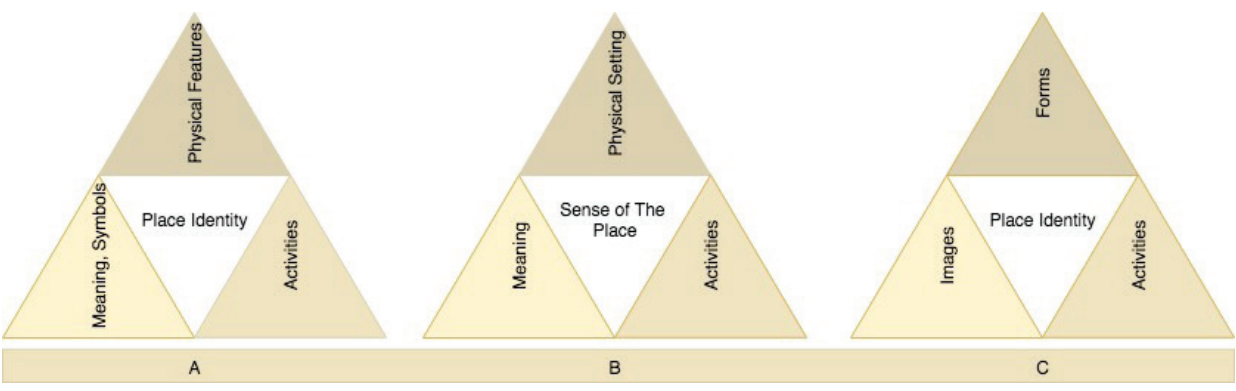

F. 2: The elements of Place identity according to A. Relph; B. Punter; C. Montgomery (Adapted by the author)

According to these definitions, the concept of identity has general parameters and features as seen in Table 2. However, these dimensions may not be complete and absolute.

24 Marilena Vecco, “Genius Loci As A Meta-Concept,” Journal of Cultural Heritage 41 (2020), 225-231.

25 Mansouri Parsa and Torabi, "Explaining the Concept of Identity and Sense of Place in Residential Environment and Lifestyle," 29.

26 Maryam Ziyaee, “Assessment of Urban Identity Through a Matrix of Cultural Landscapes," Cities 74 (2018), 21-31. 
Table 2: The Identity Concept (Azadeh Rezafar, 2021).

\section{The Identity Concept}

\section{The Identity Concept's Features}

1. Uniqueness of a thing

2. Meaning and experience (play an important role in perception of the identity)

3. A dynamic phenomenon

4. Distinguished from other objects

5. Separable without being equivalent to other objects

Identity

6. Individual and unique entity

7. Logical connection of the individual with the environment

8. Physical size, tangible versus symbolic and known and experienced versus not experienced

9. Activities, meanings or images, physical setting

In urban environmental identity, the most influential paradigm is Lynch's definition of urban elements, which are identity, structure and meaning. In his study, identity is defined as distinction from other objects, while structure means a relationship to a larger pattern of other elements, and meaning means the practical and emotional value for the observer ${ }^{27}$ (F. 3). In figure 2, Lynch's concept of the urban environmental image has been summarized. As seen in this figure, alongside structure, identity forms the physical parts of the environmental image. Therefore, it can be hypothesized that identity deals with the physical and spatial aspects of settlements.

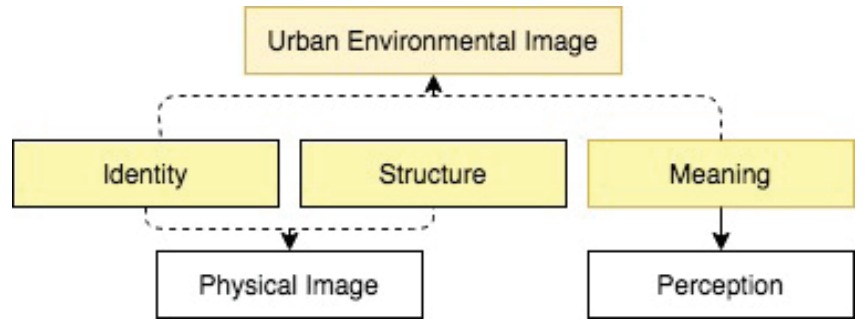

F. 3: Components of the urban environmental image according to Lynch's definition (Rezafar, "Aesthetic Control Management The case of Istanbul”, 13).

\section{Study Area}

The settlement selected for the case study is the Iranian town of Masouleh, located in the western part of Gilan province. Gilan (F. 4) is in the higher altitude areas of northern Iran just south of the Caspian $\mathrm{Sea}^{28}$. Gilan Province can be divided into

27 Rully Damayanti and Florian Kossak, "Extending Kevin Lynch's Concept of Imageability in Third Space Reading; Case Study of Kampungs, Surabaya, Indonesia," ITU Journal of the Faculty of Architecture, A|Z, 13/1 (2016), 57-67.

28 Amini, “A Comparison Study of Vernacular Settlemnets in Iran; Case of Masouleh and Abyaneh Villages," 50. 
three climatic regions: the eastern region consists of a plain, the center of the province is forested, and the western region, which is where Masouleh is located, is mountainous $^{29}$. To the south, the city is bound by the Alborz Mountains, while to the east there is a plain. These geographical features create very specific weather conditions through the combination of heavy rain and humid weather. As a result, Masouleh has hot summers and cold winters. The climate conditions are one of the most important parameters in the formation of its particular building morphology. Air conditions, spatial characteristics and traditional materials form the architectural solutions to this climate situation. The appropriate orientations and heights of the buildings are among the planning and architectural solutions.

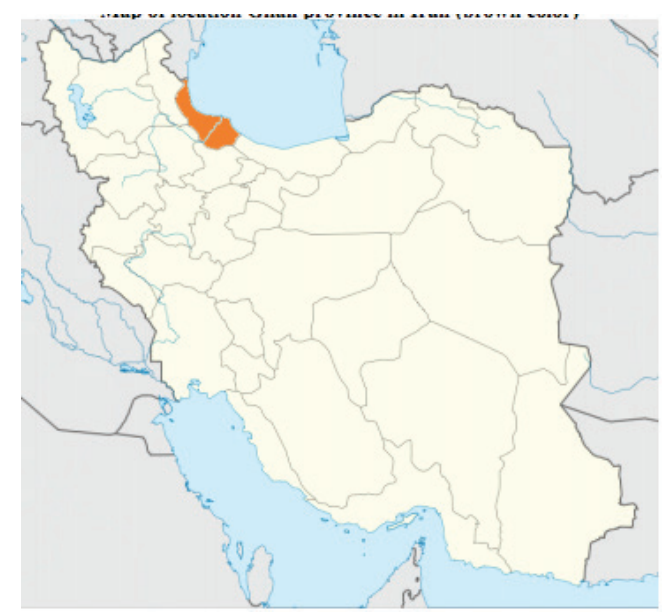

F. 4: The Location of Gilan Province in Iran,

(Sharbatian et al, “Anthropological Study of Folk Music in Gilan Province in Iran,” 26).

Masouleh's buildings expanded in an east-west linear direction in order to provide enough sunlight and local airflow for their inhabitants. At the same time, roofs of traditional houses are built with two or four slopes, and a balcony is built to prevent rain from hitting the building's body or the building's façade ${ }^{30}$. The urban texture contains discrete building units with vast open courtyards to ensure adequate airflow. This situation differs according to increasing land values in the city center.

\subsection{Masouleh as a Case of Vernacular Settlement}

A settlement expressing a wonderful harmony between nature and humans, Masouleh was designed and created under the influence of culture on the one hand and nature

29 Vahid Ghobadian, Climatic Investigation of Iran Traditional Buildings (Tehran: Tehran University Publications, 1998), 38-50.

30 Mahshid Kakouei, Mina Kakouei, Kumaran Suberamanian, Sabzali Musa Kahn, Afshin Jahangirzadeh and Shatirah Akib, "Masouleh: a City; a History," International Journal of Social, Behavioral, Educational, Business and Industrial Engineering 6/11 (2012), 2843-2848. 
on the other ${ }^{31}$. The height of the settlement, which includes about 700 residences, is 1050 meters above sea level ${ }^{32}$. A mild climate, breathtaking scenery, stepped architectural forms and fresh air are the main features of Masouleh ${ }^{33}$. This area is more than 800 years old and, due to its historical importance, it was registered in the National Architecture Index in 1976. Field research began to record this amazing human heritage for publication by UNESCO in $2011^{34}$. Masonry buildings in stepped architectural patterns and flat structures, which follow the mountain's slope, define the texture of the city. Access is along two longitudinal lengths with a slope of ground, which is in harmony with the slight slope ${ }^{35}$ and the transverse direction in which the roofs were buil $t^{36}$. This texture does not make it possible for motor vehicles to enter the area. ${ }^{37}$
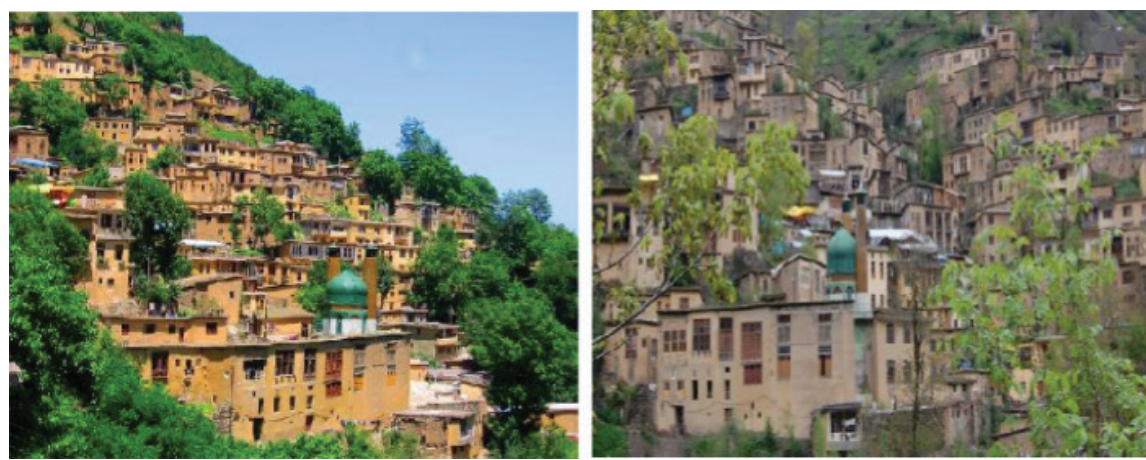

F. 5: a. Masouleh City (Imani Emadi, et al, "Sustainable Architecture Analyses of Stepped Village, Case study: Masouleh, Iran”, 152), b. Masouleh City (Hasanpour Loumer and Rayat Zadeh, "A study on consistency with principle of green architecture in Masouleh", 8593).

This high-density housing is created using natural environmental factors that created coordination and integration between housing and the environment. Interesting-

31 Kakouei, Kakouei, Suberamanian, Kahn, Jahangirzadeh and Akib, "Masouleh: A City; A History,” $2843-$ 2848.

32 Maryam Imani Emadi, Maryam Ghasemi, Sina Osivand and Farshid Roudi, "Sustainable Architecture Analysis of Stepped Village, Case Study, Masouleh, Iran," Recent Advances in Energy, Environment and Development (Greece: WSEAS Press, 2013), 152-157.

33 Saeid Hasanpou Luomer, Hasan Sattari Sarbangholi and Sahar Toofan, "Designing the Residential Place for Tourists Based on Environmental Factors and Green Architecture: A Case Study in Historical City of Masouleh," European Journal of Natural and Social Sciences, Architecture, Urbanism and Civil Engineering 3/4 (2014), 39-46.

34 Seyyedeh Roqieh Ghasemi, Mozhdeh Torkaman and Maryam Gholipour, "Recognition of Historical Landscape of Masouleh, Technical Drawing of Residential House Façade (Historical Village in North of Iran)," (International Conference on Architecture Built Environment: Redefining the Concept of Islamic Architecture and Built Environment 7th \& 8th November 2013, Conference Proceeding (Kuala Lumpur: International Islamic University Malaysia, 2013), 332-338.

35 Hasanpour Luomer and Sattari Sarbangholi Toofan, "Designing the Residential Places for Tourists Based on Environmental Factors and Green Architecture: A Case Study in Historical City of Masouleh,” 39-46.

36 Saeid Hasanpour Loumer and Faraz Rayat Zadeh, "A Study Consistency with Principles of Architecture in Masouleh,” International Journal of Current Life Science 4/10 (2014), 8589-8594.

37 Saeideh and Farnian, "Sustainable and Functional Architecture in Rural Areas: Case Studies of Abyaneh and Masouleh in Iran," Journal of Basic and Applied Scientific Research 6/10 (2016), 23-30. 
ly, these buildings, which meet the ecological needs, environmental conditions, and daily activities of the residents ${ }^{38}$, utilize forms that are influenced by the high rate of rain and humidity ${ }^{39}$. The Bazaar plays a role in the city's commercial life and the city center is the most fundamental factor shaping the city. The neighborhoods fan out around it. At the same time, the buildings' stair texture creates public spaces and courtyards for residents, as the roof of the lower unit becomes the social yard for the upper unit, and the roofs of many houses are connected directly to their neighbors ${ }^{40}$. Walking across the rooftops is a common lifestyle and an aesthetic perspective. This is a gathering place for residents to conduct different rituals and ceremonies. In short, roofs are the focal points of public life, and provide residents different vantages from which to enjoy the natural scenery and scenes ${ }^{41}$.

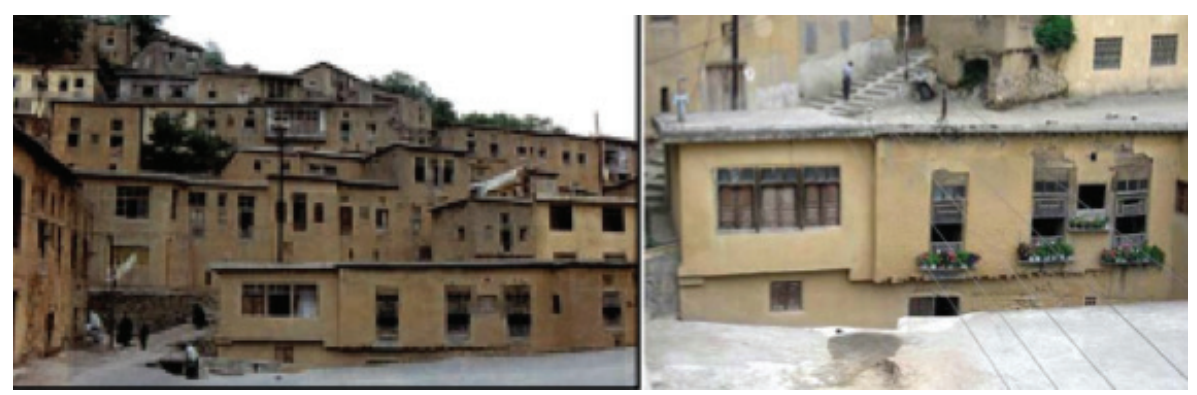

F. 6: Architectural texture of Masouleh (Imani Emadi, et al, "Sustainable Architecture Analyses of Stepped Village, Case study: Masouleh, Iran,” 152); (Kakouei et al, "Masouleh: A City;

A History," 2846).

These distinctive features of the city are the main reason for its attraction as a tourist site. There are many notable design elements in the urban-rural landscape of the city. One of these is the proximity of the buildings with the extrovert form. Another is that two or three floors are in accord with the natural topography, with the non-residential areas generally located on the lowest floor and the main corridor. A further feature is the yellow clay mud for the facade with verandas and wooden windows, which look like a part of nature. The many geraniums which bloom in the city is also seen as a distinctive landscape element. Further features include the unity of the houses with a whole view of the city, the variety and special geometric design in the old windows to protect against cold weather and provide privacy, having two or three windows set in the facade of the buildings on each side, the red-brown buildings standing on

38 Hasanpour Loumer and Rayat Zadeh, "A Study Consistency with Principles of Architecture in Masouleh," 8589-8594.

39 Imani Emadi, Ghasemi, Osivand and Roudi, "Sustainable Architecture Analysis of Stepped Village, Case Study, Masouleh, Iran," 152-157.

40 “Archdaily," access 12 May 2020, https://www.archdaily.com/880547/where-roofs-and-streets-become-oneirans-historic-village-of-masuleh.

41 Hasanpou Luomer, Sattari Sarbangholi and Toofan, "Designing the Residential Place for Tourists Based on Environmental Factors and Green Architecture: A Case Study in Historical City of Masouleh," 44. 
a sixty-degree slope, and different types of doors. Another interesting feature is that there are two types of routes, namely long parallel routes and many geographical routes that provide circulation between urban spaces in the upper and lower parts of the town. Furthermore, each citizen can use the roof of other homes as a common pathway. Finally, clay and wood, both local materials, are used in combination with other materials as well as the use of grey soil as insulation ${ }^{42}$ (F. 7). All these designs not only show the physical, ecological, and functional aspects of the region, but also reflect the history and culture of the ancient inhabitants ${ }^{43}$.
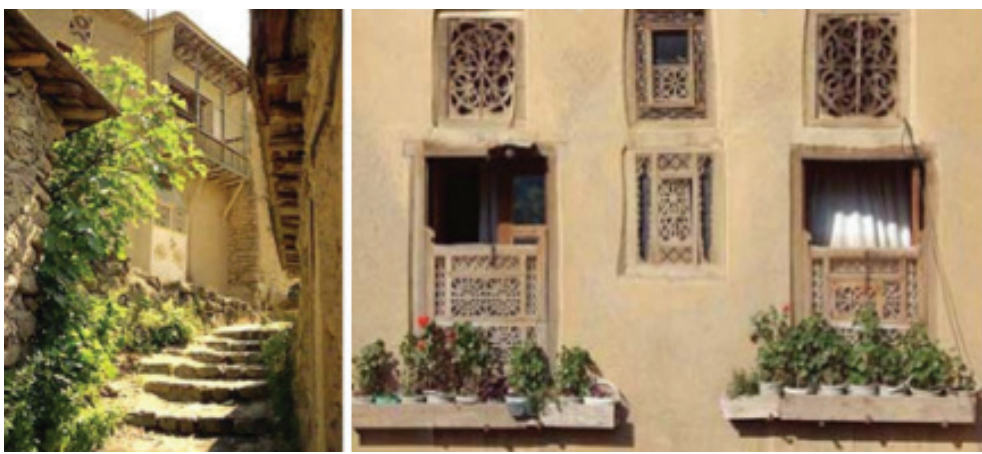

F. 7: Landscape and façade feature of Masouleh (Kakouei et al, "Masouleh: A City; A History," 2845).

These features indicate that, like other vernacular settlements, the city of Masouleh was designed and developed to meet environmental conditions and the needs of its residents. At the same time, these features indicate its sustainable development. This landscape and architecture were developed not by trained architects and urban planners, but by the residents themselves and local architects. The use of many of these parameters is bound up with the aesthetics, sustainability, and functionality of the contemporary residential area (F. 8).

42 Ghasemi, Torkaman and Gholipour, "Recognition of Historical Landscape of Masouleh, Technical Drawing of Residential House Façade," 332-338; Hasanpou Luomer, Sattari Sarbangholi, Toofan, "Designing the Residential Place for Tourists Based on Environmental Factors and Green Architecture: A Case Study in Historical City of Masouleh,” 39-46; Azam Esabegloo, Seyyed Roqieh Ghasemi, Mozhdeh Torkaman and Maryam Mohammad Gholipour, "Reclamation Vernacular Architecture Design Ruined Zones of Masouleh, Historical Village in North of Iran," (International Conference on Architecture Built Environment: Redefining the Concept of Islamic Architecture and Built Environment 7th \& 8th November 2013, Conference Proceeding (Kuala Lumpur: International Islamic University Malaysia, 2013), 354-384.

43 Ehsan Daneshyar, “A Material Culture Study of Two Houses in Masouleh, Iran” (MSc. Thesis, McGill University, 2009). 


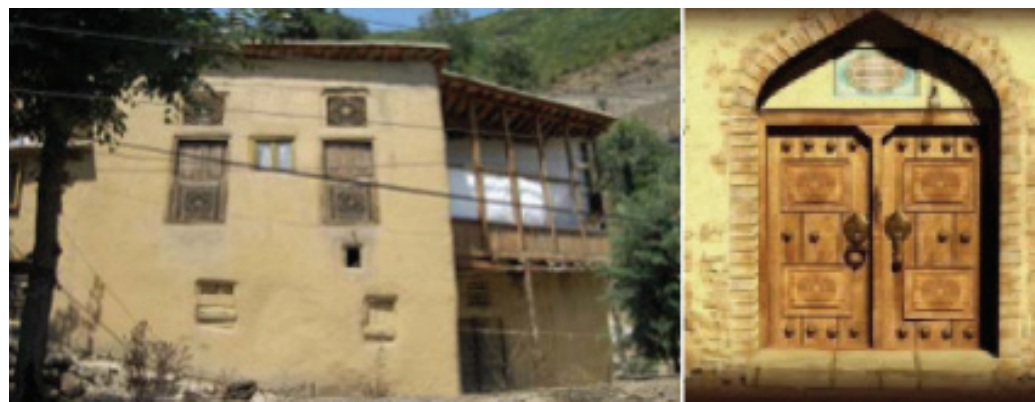

F. 8: a. Aesthetic elements in Masouleh (Kakouei et al, "Masouleh: A City; A History," 2846), b. Aesthetic elements in Masouleh (Imani Emadi, et al, "Sustainable Architecture Analyses of Stepped Village, Case study: Masouleh, Iran,” 154).

\subsection{Evaluation of the Aesthetic and Identity Parameters in Masouleh}

Masouleh as a unified and integrated city design is considered to be one of the most beautiful vernacular residential areas in Iran. My evaluation of the aesthetics of this unique urban area is based on the summation of aesthetic judgments and place identity discussed in the literature, which was summarized in tables 1 and 2. In this literature, there is more of a focus on the visual sense of beauty and aesthetics, so the visual parameters will be used here to evaluate the aesthetics of Masouleh. According to the definition of place identity, physical aspects of the settlements can be considered part of the identity concept. As such, table 3 was prepared by considering all the definitions of identity and aesthetics according to research into Masouleh's landscape and architectural features. As seen in table 3, Masouleh's notable design elements include the identity and aesthetic parameters together. For instance, ochre-brown buildings, which stand on a sixty-degree incline and provide gardens for social gatherings yards, public spaces and a street for the house above, as well as color harmony with the surrounding nature (yellow clay mud, appearing to be a part of nature), represent the dynamic phenomenon, individuality, self-sufficiency, images, colorfulness, and sensory and symbolic parameters of place identity and aesthetics. 
Table 3: The Aesthetics and Place Identity Aspects of Masouleh (Azadeh Rezafar, 2021).

\begin{tabular}{|c|c|}
\hline $\begin{array}{l}\text { Aesthetics and Identity Aspects Based on the } \\
\text { Literature }\end{array}$ & $\begin{array}{c}\text { Masouleh's Aesthetics and Identity Features } \\
\text { Based on the Research }\end{array}$ \\
\hline $\begin{array}{l}\text { Logically connection of the individual with } \\
\text { environment, } \\
\text { Protection for continuity and the natural } \\
\text { environment, } \\
\text { Being humanistic and proportionality } \\
\text { Physical setting, } \\
\text { Formal (harmony, shapes, proportions, } \\
\text { rhythms, scale), balance, proportion, } \\
\text { Geometrical beauty, } \\
\text { Green design }\end{array}$ & $\begin{array}{l}\text { Harmony between nature and human } \\
\text { Masonry buildings following the slope of the } \\
\text { mountain } \\
\text { Variety and special geometric design in older } \\
\text { windows in order to protection against cold } \\
\text { weather and keeping the privacy, existing of } \\
\text { two or three windows in the facades of the } \\
\text { buildings in all sides. } \\
\text { Geranium flowers as an unforgettable element } \\
\text { in this landscape, } \\
\text { The ecological design }\end{array}$ \\
\hline Uniq & Stairc \\
\hline Compatibility between identity and design, & $\begin{array}{l}\text { Newly architectural forms as a unified and } \\
\text { integrity city design }\end{array}$ \\
\hline Having structure as aesthetic elem & $\begin{array}{l}\text { The high-density housing developed due to the } \\
\text { use of natural environmental factors }\end{array}$ \\
\hline $\begin{array}{l}\text { ased development, } \\
\text { jects }\end{array}$ & Adjacency extrovert form of buildings \\
\hline $\begin{array}{l}\text { A dynamic phenomenon, individual, reducing } \\
\text { of information, }\end{array}$ & $\begin{array}{l}\text { Providing social yards, public spaces or streets } \\
\text { for the house above, }\end{array}$ \\
\hline $\begin{array}{l}\text { Self-sufficiency } \\
\text { Images, being colorfu }\end{array}$ & $\begin{array}{l}\text { Ochre-brown buildings stand sixty-degree } \\
\text { incline. }\end{array}$ \\
\hline $\begin{array}{l}\text { Sensory (results from the colors, odors, sounds, } \\
\text { and textures of the environment,...), }\end{array}$ & $\begin{array}{l}\text { Wooden windows and porch, adobe and wood } \\
\text { as local material in combination }\end{array}$ \\
\hline $\begin{array}{l}\text { Symbolic (experience building by way of } \\
\text { content variables, the meaning of the structure, } \\
\text { a sense of belonging to a place,..), }\end{array}$ & $\begin{array}{l}\text { Color harmony with nature and environment } \\
\text { (yellow clay mod, looking like a part of nature) }\end{array}$ \\
\hline $\begin{array}{l}\text { Tangible versus symbolic and known or } \\
\text { experienced versus not experienced, }\end{array}$ & $\begin{array}{l}\text { oression of history and culture of } \\
\text { inhabitants by design }\end{array}$ \\
\hline $\begin{array}{l}\text { Meaning and experience, positions an } \\
\text { meanings, activities }\end{array}$ & $\begin{array}{l}\text { Created with due regard to culture and } \\
\text { ecological aspects }\end{array}$ \\
\hline
\end{tabular}




\section{Conclusion}

This research tries to determine the aesthetic and urban identity parameters for the historical and touristic settlement of Masouleh. The town was developed and designed by local people according to their needs, the local culture, and the environmental context, as well as adaption to Islam. These kinds of settlement design provide the best examples of settlements that are homogeneous and created in harmony with their environment and geography, parameters that are neglected in today's heterogeneous designs. This research simultaneously discussed two complementary concepts in urban design, aesthetics, and identity, through vernacular architecture.

On the one hand, this research reveals urban environmental aesthetic and identity parameters, factors, and indicators, and on the other hand, it describes vernacular settlements with their original identity and aesthetic features. Comparing these two sides of the research, it can be seen that almost all the aesthetic and identity parameters can be found in vernacular settlements. Masouleh includes all the formal/physical, symbolic, and sensory parameters such as meaning, position and experience, being humanistic and proportional, ecological, and green design, self-sufficiency, and distinguished and dynamic phenomenon. The settlement provides all these parameters by following the slope of the mountain and staircase architectural pattern, providing social yards and gardens as well as public spaces or streets for the house above, thus responding to the influence of culture and adapting to the surrounding environment. This is important for two reasons. The first is the importance and need to maintain these areas' values for their identity and aesthetics. Tourism can bring greater economic benefits to the city. The second is that by considering these parameters in newly built settlements, more aesthetic areas can be built. This is because vernacular settlements ensure place identity by considering the native people's cultural, economic, and social needs, as well their aesthetics by considering geographical, topographical, local, and natural needs. More aesthetic designs can be formulated by analyzing the architectural dimensions of Masouleh and other vernacular settlements in detail and revealing their identity and aesthetic aspects. These parameters can be used as guidelines by different actors such as architects, urban designers and even municipalities in the future design of modern, sustainable, and aesthetic regions with the same textures.

Finally, it should keep in mind that to comprehensively evaluate the aesthetic beauty and identity of a settlement requires parameters that go beyond the formal and visual. At the same time, articulating a set of universal aesthetic principles is not possible because of the subjective dimension. 
Peer-review: Externally peer-reviewed.

Conflict of Interest: The author has no conflict of interest to declare.

Grant Support: The author declared that this study has received no financial support.

Hakem Değerlendirmesi: Dış bağımsız.

Çıkar Çatışması: Yazar çıkar çatışması bildirmemiştir.

Finansal Destek: Yazar bu çalışma için finansal destek almadığını beyan etmiştir.

\section{References/Kaynakça}

Amini, Elaheh. "A Comparison Study of Vernacular Settlemnets in Iran; Case of Masouleh and Abyaneh Villages.” M.Sc. Thesis, Istanbul Technical University, 2019.

Arbak, Şebnem. "An Analysis on the Transformation of Urban Identity, The Case of Bodrum." M.Sc. Thesis, Middle East Technical University, 2005.

Hisham Al Jarah Sivan, Zhou Bo, Rebaz Jalil Abdullah, Yawen Lu and Wenting Yu. "Urbanization and Urban Sprawel Issues in City Structure, A Case of the Sulaymanieh Iraqi Kurdistan Region." Sustainability 11/2 (2019): 1-21.

Alcolea, Ruben and Aitor Acilu. "From Sea to Stone Cradle of Avant-Garde." Surveys on Vernacular Architecture, Their Significance in the 20th Century Architectural Culture Conference Proceedings, (Porto, ESAP, 2012), 83-97.

Dahabreh, Saleem. "The Aesthetics Symptoms of Architectural Form: The Case of Barcelona Museum of Contemporary Art by Richard Meier," International Journal of Engineering Research and Technology 13/ 6 (2020): 1409-1419.

Cavalcanti, Maria de Betani. "Aesthetics and the Use of Local Resurces: The Folk Built Environment of Inland Pernambuco.”, IAPS 14 Book of Proceedings, (Stockholm, Sweden, 1996), 235-242.

Daneshyar, Ehsan. “A Material Culture Study of Two Houses in Masouleh, Iran.” MSc. Thesis, McGill University, 2009.

Damayanti, Rully and Florian Kossak. "Extending Kevin Lynch's Concept of Imageability in Third Space Reading; Case Study of Kampungs, Surabaya, Indonesia." ITU Journal of The Faculty of Architecture $A \mid Z$ 13/1 (2016): 57-67.

Esabegloo, Azam, Seyyed Rogyeh Ghasemi and Mozhdeh Torkaman. "Reclamation Vernacular Architecture Design Ruined Zones of Masouleh, Historical Village in North of Iran". International Conference on Architecture Built Environment: Redefining the Concept of Islamic Architecture and Built Environment 7th \& 8th November 2013, Conference Proceeding. Kuala Lumpur: International Islamic University Malaysia, 2013, 354-384.

Eldemery, Ibrahim Mustafa. "Globalization Challenges in Architecture.” Journal of Architecture and Planning Research 26/4 (2009): 334-354.

Farnian, Saeideh. "Sustainable and Functional Architecture in Rural Areas: Case Studies of Abyaneh and Masouleh in Iran." Journal of Basic and Applied Scientific Research 6/10 (2016): 23-30.

Ghasemi, Seyyed Rogyeh, Torkaman Mozhdeh and Gholipour Maryam. "Recognition of Historical Landscape of Masouleh, Technical Drawing of Residential House Façade (Historical Village in 
North of Iran)." International Conference on Architecture Built Environment: Redefining the Concept of Islamic Architecture and Built Environment 7th \& 8th November 2013, Conference Proceeding. Kuala Lumpur: International Islamic University Malaysia, 2013, 332-338.

Ghobadian, Vahid. Climatic Investigation of Iran Traditional Buildings. Tehran: Tehran University Publications, 1998.

Greuther, Jörg Kurt. Aesthetics in Architecture. Tehran: Publication Beheshti University, 2004.

Hasanpou Luomer, Saeid, Hasan Sattari Sarbangholi and Sahar Toofan. "Designing the Residential Place for Tourists Based on Environmental Factors and Green Architecture: A Case Study in Historical City of Masouleh." European Journal of Natural and Social Sciences, Architecture, Urbanism and Civil Engineering 3/4 (2014): 39-46.

Hasanpour Loumer, Saeid and Faraz Rayat Zadeh. "A Study Consistency with Principles of Architecture in Masouleh.” International Journal of Current Life Science 4 /10 (2014): 85898594.

Hosseini, Bahareh and Atefeh Zand Karimi. "A Brief Survey on the Principles of Iranian Islamic Architecture." Archi-Cultural Translations through the Silk Road 2nd International Conference, Mukogawa Women's University, Nishinomiya, Kapan, July 14-16, 2021 Proceedings. Nishinomiya: Mukogawa Women's University Press, 2012, 318-323.

Imani Emadi, Maryam, Maryam Ghasemi, Sina Osivand, and Farshid Roudi. "Sustainable Architecture Analysis of Stepped Village, Case Study, Masouleh, Iran," Recent Advances in Energy, Environment and Development. Greece: WSEAS Press, 2013, 152-157.

Kakouei, Mahshid, Mina Kakouei, Kumaran Suberamanian, Sabzali Musa Kahn, Afshin Jahangirzadeh and Shatirah Akib. "Masouleh: a City; a History." World Academy of Science, Engineering and Technology, International Journal of Social, Behavioral, Educational, Business and Industrial Engineering 6/11 (2012): 2843-2848.

Lang, Jon. Symbolic Aesthetics in Architecture: Toward a Research Agenda. New York: Cambridge University Press, 2013, 11.

Mansouri Parsa, Rogayeh and Zohreh Torabi. "Explaining the Concept of Identity and Sense of Place in Residential Environment and Lifestyle, Kuwait." Chapter of Arabian Journal of Business and Management Review 4/5 (2015): 27-43.

Nasar, Jack. "Urban Design Aesthetics the Evaluative Qualities of Building Exteriors." Environment and Behavior 26/3 (1994): 377-401.

Pirhadi, Mana, Maryam Pirhadi and Fatemeh Tavakoli. "The Study of the Concept of Aesthetics in Architecture Derived From the Ideas Of Jörg Kurt Greuther." World Academy of Science, Engineering and Technology, International Journal of Urban and Civil Engineering 4/5 (2017): $1-7$.

Pirnia, Mohammad Karim. Stylistics of Iranian Architecture. Tahran: Pazhuhande Publishing, 2003, 26-36.

Reza, Ehsan. "Identification of Staircase House Type in Rural Architecture of Iran: Masouleh and Abyaneh Settlements.” MSc in Architecture, Eastern Mediterranean University, 2011.

Rezafar Azadeh and Sevkiye Sence Turk. "Urban Design Factors Involved in the Aesthetic Assessment of Newly Built Environments and Their Incorporation into Legislation: The Case of Istanbul." Urbani-izziv 29/2 (December 2018): 83-95.

Rezafar, Azadeh. “Aesthetic Control Management, The Case of Istanbul.” Ph.D. Thesis, Istanbul 
Technical University, 2019.

Shoaie, Hamidreza and Farah Habib. "Iranian Sustainable Vernacular Architecture." Advance in Environmental Biology 7/13 (2013): 4451-4459.

Sahebzadeh, Sadra, Abolfazl Heidari, Hamed Kamelnia and Abolfazl Baghbani. "Sustainable Features of Iran's Vernacular Architecture: A Comparative Study Between the Architecture of Hot-Arid and Hot-Arid-Windy Regions.” Sustainability 9/5 (2017): 1-28.

Sharbatian, Yaghoub and John S. Gaikwad. "Anthropological Study of Folk Music in Gilan Province in Iran." International Journal of Social Sciences 3/ 4 (2013): 25-34.

Uttara, S., Bhuvandas, Nishi and Vanita Aggarwal. "Impacts of Urbanization on Environment." International Journal of Research in Engineering \& Applied Sciences IJREAS 2/2 (2012): 16371645.

Vecco, Marilena. “Genius Loci as A Meta-Concept.” Journal of Cultural Heritage 41 (2020): 225231.

Ziyaee, Maryam. "Assessment of Urban Identity Through a Matrix of Cultural Landscapes." Cities 74 (2018): 21-31.

Archdaily, Access May 15, 2020. https://www.archdaily.com/880547/where-roofs-and-streetsbecome-one-irans-historic-village-of-masuleh 